\title{
An evaluation of Anti-Terrorism laws in Pakistan: Lessons from the past and challenges for the future
}

\author{
Ayesha Jawad
}

jawad.ayesha@gmail.com

(D)https://orcid.org/0000-0001-6676-9822

Nadira Hassan Law Department, Kinnaird College for Women, 93-Jail Road, 54000, Lahore, Pakistan

\begin{abstract}
Terrorism has changed the national and international security milieu over the last few years; however, there have been metamorphoses in the phenomenon of defining security in light of new threats of terrorism. This research critically evaluates the anti-terrorism legal regime of Pakistan along with its structural flaws. While vigorous efforts to defeat terrorism have taken place in Pakistan, much needs to be done to achieve de-radicalisation along with identifying and addressing areas of vulnerability. This research moves in three directions: firstly, it looks into the background of extremism in terms of ethnic and sectarian conflicts that led Pakistan to embark on the journey to combat terrorism; secondly, it evaluates how these laws aimed exclusively at countering terrorism have not been as effective as hoped; and thirdly, it offers an in-depth analysis of flaws in the judicial system and analysis of capacity gaps in relation to prosecution of terrorist offences in Pakistan. Lastly, this research makes recommendations for eliminating the causes of institutional and legal inefficiencies that feed and nurture terrorism in Pakistan. The qualitative method is used in this research, which holds that Pakistan needs to make effective structural changes to implement counterterrorism strategies constructively, such as, capacity-building of judiciary and law enforcement agencies, acceptance of innovation in investigation methods, amendments in procedural laws and comprehensive, unambiguous and detailed legislation. Amendments to existing anti-terrorism laws need to be adapted to the changing security trends in the region. In order to combat the high rate of acquittal under these laws, a strong and focused approach is required.
\end{abstract}

\section{Keywords:}

Pakistan, security, counterterrorism, anti-terrorism laws 


\section{Introduction}

$\mathrm{T}$ errorism and counterterrorism acquired a new connotation after 9/11. The need to find a legal and just answer to the new "crime," both these fields have evolved phenomenally in the wake of 9/11. The violent attacks on the World Trade Centre not only changed the dynamics of national and international security but also altered the criminal justice response to terrorism. Owing to the changing environment of the international system, the need to retain the already understood definition of terrorism would become even murkier following the US's dramatic exit from Afghanistan in August 2021. The exit alone has not only caused significant damage to the fragile security of the Afghan people but also has opened a Pandora Box of security challenges for Pakistan. With the recognition of the Taliban government, Pakistan, being a frontline state in the Global War on Terrorism (GWOT) and with its internal disturbances, has anti-terrorism laws that have often been criticised by international human rights organisations. States have been facing this menace of terrorism for ages, but the attack on the twin towers as an attack on American hegemony magnified it. Pushing the international community into the GWOT, it undoubtedly transformed the perspective of the states towards each other. The states are categorised as allies, enemies and rogue states.

The world experienced and witnessed the most significant paradigm shift in world politics, where the states were fighting with a relatively equal non-state actor instead of a state as per traditional security milieu. Fighting with an ideology rather than a traditional enemy, the international community became highly sceptical of some Muslim states such as Iraq, Iran, and Afghanistan.

Pakistan though, due to its geo-strategic location, became a dynamic actor and a default ally in this power play of the contending forces in this war. While sharing a long hostile history with its neighbours, including Afghanistan, Pakistan had to take sides and this time a relatively powerful side was chosen. Nevertheless, Pakistan paid a heavy price for this involvement in war and, as termed "trust deficit" by observers, it has not been able to meet the expectations of the United States of America (Fair, 2012, p. 100). Despite its open support for the US in this war, Pakistan has repeatedly fallen under strict examination over accusations of being an accomplice to the Islamic militants. The attack was considered a blow to American liberalism, and a global threat that urged the international community to recognise and accept the incident of the Twin Towers as a terrorist act.

Therefore, the international response to the event included the United Nations (UN, 2019) calling out states to show solidarity in this global war and it ended up passing many resolutions in this regard. United Nations General Assembly (UNGA) Resolution, 2001, United Nations Security Council (UNSC) Resolutions 1368, 1373, condemn terrorist attacks and called on states to make perpetrators, organisers and sponsors accountable (US Department of State, 2006). The UNSC established a Counter-Terrorism Committee and in Resolution 1373 called for states to work together to prevent and suppress terrorist activities by implementing the International Conventions. Along with the other responsibilities and obligations stated in the above-mentioned resolutions, member states had multifaceted legal issues and challenges to address. The crucial challenge has been striking a balance between international responsibilities and domestic legislation.

Among all the states that became direct stakeholders in the War on Terror, the Islamic Republic of Pakistan, in particular, possessed a challenging societal structure along with the border issues with its neighbours. Pakistan remains one of the most vulnerable states in this war besides being the most significant. From the issues of missing persons to the increased terror attacks internally, Pakistan found itself changing security archetypes. 
Nevertheless, this challenging situation has taken a critical twist in the post-withdrawal phase of American forces in Afghanistan. With the Taliban's takeover of Kabul, Pakistan is tangled up with various internal and external pressures: the increased expected border fragility, and the internal rise of religious bodies both for and against the Taliban in the neighbourhood all pose security challenges for Pakistan.

However, it is worth mentioning that dealing with terrorism and radicalism is not a new phenomenon for Pakistan. In the wake of regional events such as Pakistan's involvement in the proxy war of Afghanistan in 1978, along with the Islamic revolution in Iran, Pakistan fell right into the trap of Islamisation and Islamic militancy. These events changed the whole dynamics of Pakistan's politics and state structure. The narrow interpretation of Islam through the Sunni sect during the Zia regime pushed the country into the lap of sectarian militancy and created top-down Islamisation (Nasr, 2000, p. 175). The Jihadi outfit, mixed with sectarian violence, put Pakistan on the road of contending with terrorism from the 1970s. Furthermore, Pakistan's long and diverse struggle to deal with militancy on its land, be it sectarian, lingual or ethnic, has called for latitude from legal normal procedure (Kennedy, 2004, p. 388). Hence, the government of Pakistan worked on creating robust counterterrorism laws. However, the changing narratives of terrorism in Pakistan call for a re-evaluation of these laws, particularly with the Taliban establishing a government in Afghanistan. This paper delineates the anti-terrorism laws of Pakistan while looking at their legal and execution efficacy. This paper gives some recommendations after analysing the criminal justice system in lieu of the counterterrorism laws of Pakistan. However, to analyse the existing laws of terrorism in Pakistan, it is pertinent to dig deep into the history of this legislation.

This research is qualitative as it focuses on both primary and secondary sources. This study derives its data from documents, research papers, newspapers and statute analysis in the wake of current political-legal dimensions to analyse the counterterrorism regime of Pakistan.

\section{Brief history of Pakistan's Anti-Terrorism Laws}

$\mathrm{T}$

he fight against terrorism is difficult to win by merely criminalising the main act caus-

ing death and suffering. It is firstly important to analyse the criminological aspects of it that stem from inchoate offences. Offences such as encouraging, counselling, aiding and abetting, and procuring terrorists and terrorist acts are informed by the notion of global jihad. The response of the law towards discouraging such acts in a predominantly Muslim society is worth investigating. So far, most trials of terrorist suspects target those who are fighting the government. Special courts have been created under the Anti-Terrorism Act, 1997 (ATA), Protection of Pakistan Act, 2014 (POPA) and the twenty-first amendment to the Pakistani Constitution 2015, which established military courts for trying terrorists. These laws were added to the two primary statutes, the Code of Criminal Procedure, 1898 and the Pakistan Penal Code, which also provide for terrorism-related offences. The objective of this study is to identify the gaps in these laws and how these gaps can be filled whilst keeping in mind the new security challenges.

\section{Pakistan and its history of dealing with terrorism Pakistan and the protracted issue of extremism}

Since its birth, Pakistan has contested terrorism in one way or another, ranging from S traditional and non-traditional extremism, armed conflicts to sectarianism (Malik, 
He and Rafay, 2019, p. 627). Since the Zia regime, 1978-1988, Pakistan fell into the trap of sectarian and communal violence, which worsened over the period. Undoubtedly, one can say that the policies of the Zia regime were responsible for radicalising Pakistan. Organisations such as Tehreek-e-Nafaz-e-Fiqh-e-Jafaria (TNFJ) and Sipah-e-Sahaba were established during the Zia regime, exacerbating the sectarian conflicts and also flaunting governmental support to some extent. Henceforth, Pakistan was divided into factions based on sectarianism; later on, the split in the TNFJ also paved the way for Iran and Afghanistan in their violent activities against Pakistan. (Refugee Review Tribunal Australia, 2008, p. 11). The seed of Islamic militancy, intolerance and extremism sowed during that period affected Pakistan's entire security environment later with full force.

Various small-scale conflicts took place among these radical sectarian organisations; however, few of those became catalysts in drafting the counterterrorism legal regime. Along with the other violent events, Shia militants of TNFJ killed 23 in a district court blast in February 1997 along with the leaders of the Sunni movement, and the government of that time was urged to revise its legislation, enacting the counterterrorism regime. The then Prime Minister, Mr. Nawaz Sharif's administration moved a bill for anti-terrorism laws in the National Assembly and got it passed by an overwhelming majority. However, one can clearly identify lacunas in the existing laws of counterterrorism due to the changing nature and meaning of security. In addition, those laws proved not to be very effective due to various supplementary factors, particularly the ineffectual structure of the criminal justice system.

\section{Pakistan and the legal regime of Anti-Terrorist Laws Road to promulgation of Anti-Terrorist Laws (ATA), 1997}

$\mathrm{T}$ he incessant growth of terrorism worked as a background apprehension for Pakistan to combat this menace through conscious legislative efforts; hence, Pakistan adopted its anti-terrorism laws in 1997 to deal with extremism and radicalism. The Anti-Terrorism Act 1997 (ATA) proved to be the first clear and explicit law on counterterrorism in Pakistan. This statute embodies in it the substantive and procedural laws along with schedules explaining terrorism in a wider spectrum. Before the ATA, offences that had been similar to the felony of extremism, such as crimes against the state and incitement, were covered under the Criminal Procedure Code 1898 and Pakistan Penal Code 1860. Nevertheless, the Act passed and strategies adopted included offences from sectarian violence, terrorism, hi-jacking, use of explosives, to kidnapping. This particular Act also enables Pakistan's government to take actions against proscribed organisations under the ATA's fourth schedule. This Act, to date, has undergone multiple amendments but it still cannot be rightly called perfect legislation in the present security milieu.

Furthermore, the ATA was enforced through specialist Terrorist Courts, which generated a debate amongst the scholars regarding the militarisation of legal proceedings. The establishment of anti-terrorist courts (ATC) to deal with the backlog of the cases seemed to further complicate the system. Due to the vast and somewhat vague definition of terrorism in the ATA, ATCs were burdened. Nevertheless, with all the imperfections and hitches, the ATA was undoubtedly a bold departure from the normal legislation of the State.

As this law was drafted in the aftermath of protracted sectarian violence and conflicts, it therefore gave a broad definition of Terrorism. This definition of terrorism often comes under scrutiny due to its broad context and vague language. Insertion of the "third 
schedule" annexed to the ATA in 1999 further broadened the definition of terrorism by including more offences under the jurisdiction of ATC (Anti-Terrorism [Amendment] Ordinance, 2001; Public Procurement Regulatory Authority (Pakistan), 2001).

Under Section 6 of the ATA, terrorism is defined as follows:

Whoever, to strike terror in the people, or any section of the people, or to alienate any section of the people or to adversely affects harmony among different sections of the people, uses bombs, dynamite or other explosive or inflammable substances, or fire-arms, or other lethal weapons or poisons or noxious gases or chemicals or other substances of a hazardous nature in such a manner as to cause, or to be likely to cause the death of, or injury to, any person or persons, or damage to or destruction of, property or disruption of any supplies of services, essential to the life of the community or displays fire-arms, or threatens with the use of force public servants to prevent them from discharging their lawful duties commits a terrorist act. (Anti-Terrorism Act, 1997).

The difficulty of measuring factors that led to the drafting of the Anti-Terrorism Act in Pakistan, as mentioned earlier, meant this Act passed and implemented in 1997 was a long way from perfection. However, before analysing the regime of Pakistan's national laws against terrorism, it is imperative to introduce the complete national legislation of counterterrorism before the enforcement of the ATA in 1997.

\section{Anti-Terrorism Laws in Pakistan}

A mentioned, Pakistan's main chief legislation on criminal laws is the Pakistan Penal Code, 1860 (PPC), inherited from the British, with amendments to make it coherent with Islamic values; the PPC is not a complete code to deal with the crimes of terrorism. However, sections such as 122 deal with the offences of waging/attempting to wage war against Pakistan, collection of arms to wage war, section 124, sedition, section 131 of mutiny, mischief and hijacking in Section 46 and 402-B and C are elaborated in detail in the PPC (Pakistan Penal Code, 1860). Nevertheless, the Pakistan Penal Code could not prove to be comprehensive legislation to deal with the changing traits of security.

Along with the PPC, Pakistan drafted special legislation "Suppression of Terrorist Activities (Special Courts) Acts (1974 to 1997)". The need for special legislation was felt by the State to curb the prolonged sectarian violence in Pakistan in the wake of the Zia regime. This special legislation includes "Suppression of Terrorist Activities (Special Courts) Act 1975", passed and effected prior to the Zia regime, "Special Courts for Speedy Trial Ordinance 1987", "Terrorist Affected Areas (Special Courts) Ordinance 1990", "Special Courts for Speedy Trials Ordinance 1991" and "Special Courts for Speedy Trials Act 1992". However, this series of special legislation did not prove to be effective, hence, the world witnessed Pakistan going deep into a swamp of terrorist activities such as target killings, sectarian conflicts, especially in Karachi, more and more in the next few years.

Furthermore, sectarian conflicts as mentioned above paved the way for a counterterrorism legal regime in Pakistan, starting from 1997. Finally, Pakistan saw its primary and substantive, comprehensive law focusing on terrorists i.e. the Anti-Terrorism Act 1997 (ATA). However, with time, this Act did not prove to be proficient, hence creating complications and challenges in its implementation.

One can argue that the focus of ATA should shift from inter-communal conflicts to terrorism to avoid a backlogging of cases. However, this does not address the landscape of 
terrorism in Pakistan due to the numerous causes that of crime and primarily because this regime was initially promulgated to counter the inter-communal rifts among different sects. At the time of its inception, the security challenge was evident and transparent; however, with the GOWT, security challenges in Pakistan took a heterogeneous shape involving various actors and, above all, ideological actors.

\section{Critical evaluation of Anti-Terrorism Act, 1997}

$\mathrm{M}$

ichael (2007, p. 37) contends that one of the most affected countries regarding terrorism is Pakistan. Pakistan has not only lost its people to it but also it has had an enormous impact on its economy, international image and civil rifts (Looney, 2004, p. 774). It is noteworthy that almost 25 years after this legislation, it has failed to provide the expected outcomes. For instance, the acquittal of all four suspects in the 2010 Marriott Hotel bombing that took place in 2008 generated serious concerns regarding the efficacy of this Act (Dawn, 2010). In this attack alone, 54 people were killed and around 200 injured, not to mention the mental impact of this attack in the heart of the capital. The suspects were acquitted due to a lack of admissible evidence. Additionally, the acquittal of the main accused in Daniel Pearl's case by Pakistan's Supreme Court in 2012 (Bhatti, 2021) is one of the few examples of Pakistan's lackadaisical approach regarding the implementation of the ATA. This makes it evident that Pakistan does not possess a strong responsive criminal prosecution structure required to implement this legislation. These among many acquittals posed serious questions about the systemic flaws in Pakistan's criminal justice system, especially in dealing with cases related to terrorism.

Moreover, trials by ATC are commonly delayed by frequent adjournments, creating a backlog of cases. In a landmark judgment "Liaqat Hussain vs. Federation of Pakistan, 1999", the court adopted the "zero inventory" approach (Supreme Court of Pakistan, 1999). It was also decided that ATC will be given one case at a time; however, this was affected by the broad definition of Terrorism, which due to its vastness includes many offences punishable under this Act which would otherwise have been tried under the Pakistan Penal Code.

However, one can see that more than being overburdened by the cases, ATCs suffer from a poor case management structure. The absence of witness protection, unlimited adjournments, poorly equipped law enforcement agencies, and religious pressure groups is a matter of concern for the high rate of acquittals. Delaying tactics used in courts undoubtedly affect the evidence and witnesses, hence conviction rates are lower. Moreover, the ATA works differently than other special laws of Pakistan as it puts a burden of proof on the prosecution and the prosecution has to establish the case. Furthermore, while evaluating the ATA, one can perceptibly realise that the prosecution has to prove the case against the accused "beyond the shadow of doubt" rather than just on a "balance of probability." Inherent flaws in the counterterrorism regime along with the crippled criminal justice system has made this war against terrorism more challenging and demanding for Pakistan. This paper investigates that to fulfil its obligations under international law, and to make existing legislation, Pakistan requires a more robust and comprehensive approach. To keep pace with international obligations, Pakistan introduced many new laws post 9/11 and amongst them was the Anti-Terrorism Amendment Ordinance 2002, passed on $10^{\text {th }}$ January 2002. This Ordnance specifically focused on the conducting of speedy trials of the pending cases of terrorism. However, its structure and the inclusion of armed personnel in the proceedings stirred serious debate amongst the jurists, policymakers and academics. This Ordinance, unprecedented as ever, allowed army personnel with the minimum rank of Lt. Colonel to be members of the ATC. Keeping in mind the history of the military with 
political institutions in Pakistan, this raised many questions on the credibility of the judiciary as an institution. Furthermore, the stringent penalties introduced by this Ordinance stimulated deliberation amongst the policymakers as well as human rights defenders.

To make the ATA effectively applicable, various procedural changes were introduced through judicial activism. In a landmark case, the Mehram Ali case (Supreme Court of Pakistan, 1998, p. 1445), many important points were raised. This judgment, significantly, became the source behind all the amendments to the ATA, calling various provisions of the Act ultra vires. Through this judgment, the Criminal Procedure Code and Laws of Evidence (Qanoon-e-Shahadat, 1984) were made applicable to the trial of an offence under the ATA.

The proviso of the CrPC 1898, which is a self-contained code for the holding of criminal trials, has been made applicable to the proceedings before a special court and for the said provisions of the codes. A special court shall be deemed to be a court of the session under section 32 of the ATA. Under Article 1(2) of Laws of Evidence, 1984, its operation extends to the whole of Pakistan and applies to all juridical proceedings in Pakistan. (Supreme Court of Pakistan, 1998, p. 1500).

It was also noted in the above-mentioned case that

Indeed, different laws can validly be enacted for different sexes, persons from different age groups with different financial standing and a person accused of heinous crimes. However, this does not mean that a parallel judicial system can be created in violation of Articles 175, 202 and 203 of the Constitution. There can be special courts trying heinous crimes expeditiously, but the same should be within the framework of the Constitution. (Supreme Court of Pakistan, 1998, p. 1479)

The judgment of this case was later reinforced in Shaikh Liaqat Hussain vs. Federation of Pakistan, (Supreme Court of Pakistan, 1999).

\section{Amendments in the ATA and their effect on counterterrorism policies}

- Anti-Terrorism (Amendment) Ordinance XXXIX of 2001: Following this enactment, the government banned two militants and sectarian organizations, i.e. Lashkari-Jhangvi and Sipah-i-Mohammad. In addition, this amendment allowed the government to seal their assets if found to be involved in terrorism or terrorist activities in the State. This was a positive step towards curbing terrorist financing. After this amendment, the proscribed organisations, under the Fourth Schedule of the ATA, were not able to carry out any monetary transactions.

- Anti-Terrorism (Amendment) Ordinance VI of 2002: To speed up the trial of the pending cases along with increasingthe single bench to three members, including one military personnel. However, this inclusion of military personnel compromised the boundary of judiciary and military, which was further criticised by the judiciary on the pretext that the sanctity of an institution was being sabotaged.

- Anti-Terrorism (Amendment) Ordinance CXXV of 2002: Established the rule of ten months tenure for the speedy trials of the pending cases. This could not be followed in letter and spirit due to the practical technicalities involved in the process of conducting trials. 
- Anti-Terrorism (Amendment) Ordinance CXXXIV of 2002: This amendment approved further powers to the police to encounter terrorism by allowing them to keep a suspect for up to a year without filing any criminal charges. This amendment generated quite a debate among scholars and human rights activists. Moreover, the extrajudicial detention of Pakistani citizens in this regard is a clear violation of Articles 9 and 10 of Pakistan's Constitution. (Pakistani.org, 2018). This has instigated other debates like that of the "Missing Persons"; as the people were allegedly deported to third countries, especially the USA, by the government of Pakistan. While giving these powers to the Law Enforcement Agencies (LEA), the state has devised no policy to hold the agencies accountable. Less recognised accountability led to extreme violation of these powers.

- Anti-Terrorism (Amendment) Act X of 2004: Section 25 (4) victim or legal heir of the victim aggrieved by the order of acquittal passed by the ATC in a High Court. This amendment was required for the right to a fair trial.

- Anti-Terrorism (Second Amendment) Act 2004 (Act II of 2005): This Act allowed the transfer of terrorism cases from one province to another. Furthermore, in section 6 , subsection (2) after clause (e) the following clause shall be inserted: "(e) involves the use of explosives by any device including a bomb blast. This enhanced the jurisdiction of the courts in dealing with such cases as kidnapping for ransom, explosives and similar issues. Section 7(i), (ii), (iii), (iv), (v), (vi) and (vii); leading to severe punishments.

- Anti-Terrorism (Amendment) Ordinance XXI of 2009: This amendment enhanced the scope of the definition of terrorism by including an attack on government premises, official installations, schools, hospitals and other public property under the umbrella of terrorism. This amendment came in the aftermath of the Lal Masjid incident, in 2009. Keeping in mind the current situation of radicalisation in Pakistan, this clause is much needed.

- Anti-Terrorism (Amendment) Act, 2013: To ban any militant or sectarian organisation and also freeze their assets if found involved in terrorism or terrorist activities in or against the state.

- Anti-Terrorism (Second Amendment) Act, 2014: To address the shortcomings concerning the terrorism financing provisions in the Anti-Terrorism Act, 1997, covering all aspects of the crimes according to international standards and to provide for more effective measures for law enforcement agencies to investigate the offences.

\section{Appraisal of New Laws Enacted As Counterterrorism Strategy}

$A$ long with the above-mentioned amendments to enhance the powers and scope of ATC and implementation of the ATA, the following new laws were introduced:

- Anti-Money Laundering Ordinance, 2007: This law provides for the prevention of money laundering and loss of property derived from being involved in money laundering and for connected matters.

- The Prevention of Electronic Crime Act, 2007: To inhibit any act in contradiction of the privacy, integrity and accessibility of electronic systems, networks and data and 
to stop their misuse by punishing such activities. This legislation provides a mechanism for investigation, prosecution and trial of such crimes.

- Anti-Money Laundering Act, 2010: To provide for the prevention of money laundering and forfeiture of property derived from or involved in money laundering and for matters connected therewith or incidental thereto. The Act itself is robust; however, it is practically difficult for the state to keep a check on proscribed organisations' properties due to the concept of "alms" attached with such organisations.

- Action (in Aid of Civil Power) Regulations (“AACP”) in 2011: This provides the legal framework for detention of an accused. This law contains some innovative solutions as this introduces captivity as a regime whereby a miscreant can be detained during actions in aid of civil power.

- Protection of Pakistan Ordinance, 2013: This law deals with the protection against waging of war against the Pakistani state while elaborating on the prevention of acts that threaten the security of Pakistan.

- National Counter Terrorism Authority Act, 2013: To curb the threat of terrorism to receive, collate data, information and intelligence disseminate and coordinate between all relevant stakeholders to formulate a threat assessment with periodical reviews to be presented to the federal government for making an adequate and timely effort to counterterrorism and extremism.

- Protection of Pakistan Act, 2014: This Act was passed in 2014 to protect Pakistan against waging of war or insurrection against the State. This further prevents acts threatening the security of Pakistan. However, many clauses of the POPA overlap with the ATA due to its broad definition of "Enemy alien" and violations of Fundamental rights constituted in the Constitution of Pakistan, such as Article 10 (Right to Fair Trial), (The Nation, 2015). However, the government has been unable to establish POPA courts, leaving people to suffer in jails without any rule of law.

- The Prevention of Electronic Crime Act, 2016: To prevent unauthorised acts concerning the information systems and provide related offences as well as a mechanism for their investigation, prosecution, trial and international cooperation with respect thereof and for matters connected therewith or ancillary thereto.

\section{Legal and statutory gaps in ATA regime}

$\mathrm{P}$ akistan has presented a robust legal regime comprising the ATA, 1997, POPA 2014 and National Counter-Terrorism Agency (NACTA) 2013, as mentioned and explained above. However, one can see that due to its stringent laws, the incapacitated criminal justice system, and extended powers given to LEA, ATA could not achieve its chief objective of speedy trials under terrorism laws. Powers has been given under Section 3(2) (a), 10 of the ATA providing an officer of BS 15 whether of army or civil armed forces the right to shoot on sight, and authorising the LEA to enter any premises tosearch without a warrant, respectively, created a significant amount of concern among the policymakers and scholars (The Anti-Terrorism Act, 1997 1(Xxvii of 1997). Also, to justify the concept of speedy trial, the ATA gives one week for investigation post-arrest for a suspect and 7 days to conclude the trial, which is insufficient to scrutinise a case and a clear violation of the right to a fair trial under international law. This also became one of the reasons for the high rate of acquittals. 
Apart from the above-mentioned lacunas in the ATA regime, the most important remains the broad and extended definition of terrorism as mentioned earlier. It is the major weakness in the anti-terrorism legal framework in Pakistan, which has placed a considerable burden on ATCs because they were authorised and bound to try those crimes, which can be tried by ordinary courts; thus, accumulation of pending cases was the result (Imran and Qasim, 2020, p. 248). One of the challenges with the definition of terrorism under section 6 of ATA is it's being action-based. As noted in PLD 2005 Supreme Court 530, by the Supreme Court of Pakistan, "Section 6 does not revolve around the word "designated to"... or mens rea ${ }^{1} \ldots$ but the keyword, in our opinion, is action on the basis whereof it can be adjudged as to whether the alleged offence falls within the scope of section 6 of the Act." This clearly means that more emphasis should be given to the action itself in interpreting the ATA, instead of focusing on intent or motive, which narrows the implementation of the law.

This sole determination criterion of "action" has widened the scope of the definition, which eventually flooded the ATCs with offences that could be tried under already existing criminal legislation. In addition, this section contains 17 sub-sections, as this is the only decisive criteria for triggering the application under the ATA. The comprehensiveness of the definition complicates the implementation concerning the connotation of the words. For instance, the word "serious" may replace the word "grievous" in sub-section 2. Also, "grievous violence against a person or grievous bodily injury or harm to a person" can be replaced by either physical harm to a person or bodily injury, to limit complications attached to the criteria.

Moreover, the need to strengthen gaps in the investigation is imperative, and steps such as anonymity of witnesses, prolonged physical security of witnesses, building the investigative capacity of law enforcement agencies are required to make the ATA effective and productive.

The prosecution is required to prove its case against the accused "beyond the shadow of doubt" rather than just on "balance of probability" as discussed above. This raises the bar to the evidentiary standards and, to some extent, creates legal complications for the prosecution. However, there have been cases where judges have taken a diverse view and applied law indulgently. For instance, in case number 22, dated 8 March 2012, Abbottabad ATC, the Judge observed that "if the accused facing trial is benefitted on mere minor discrepancies due to inefficiency and ignorance of investigation officer, the terrorism will never end and the insecurity, uncertainty, risk to life and property of the people shall be enhanced to an endless limit." The ATA also possesses the challenge of merging the armed forces with civil forces in aiding civil administration to combat terrorism (Sec 4, ATA). However, section 4 is silent over the minimum threshold to seek deployment of the armed forces. To be compared with Article 243 of the Constitution, some clarity is still required in defining the emergency where the armed forces can be called upon.

Furthermore, to deter individuals from becoming members of the proscribed organisations, the stipulated punishment needs to be increased. Section 11EE and 11D of ATA, dealing with restrictions on individuals being members of a proscribed organisation, also lacks clarity though being extensive. Courts seem to have diverse views over the "availability of concrete material as prima facie proof" (Khwaja Mureed Hussain vs. the Government of Punjab, Home Department, Lahore: Muhammad Yousaf Farooqi vs. the Govt. of Punjab). Additionally, the restrictions as explained in 11EE are problematic due to their being unfeasibly taxing on state resources and of an extensive nature. The restrictions needed to be more targeted and specific such as putting restraint on those activities which the authorities believed pertained to furthering terrorism. 
Pakistan is required to look at the legal regime more comprehensively to deal with the recent political changes in the region. Undoubtedly, the US withdrawal has amplified the security challenges for Pakistan

\section{Security challenges and ATA: Post US withdrawal}

$\mathrm{P}$ akistan's post-9/11 strategy defines security as a significant combination of national, regional and international variables. While committing nationally to combatting terrorism, Islamabad signed and ratified international instruments such as "United Nations Convention for Suppression of Financing of Terrorism, 1999" and "International Convention for Suppression of Terrorist Bombing, adopted by General Assembly of the UN in 1997" (United Nations Office on Drugs and Crime [UNODC], 2008). Pakistan became a front ally in this War for many reasons. Keeping in mind the geo-strategic position of Pakistan, it needed to prevent itself being declared a terrorist state. As this could have adverse effects on its position as a nuclear power and eventually might have disturbed the equilibrium of power in the region. Along with this, having an adversarial government in Kabul was also not on the agenda of Pakistan from the security perspective. At that time, the need for Pakistan was twofold; to safeguard its image and to emerge as a responsible and dignified nation, vis-a-vis any other state in the region, which later proved to be a slippery slope.

This decision was termed as a matter of "national survival" (The News, 2001) changing the course of strategic priorities and security patterns for Pakistan for good. Undoubtedly, Pakistan's security milieu changed 360 degrees by changing its pro-Taliban policies to anti-Taliban. Pakistan's involvement in the war also changed the perspective of regional politics; on one hand, it strengthened the position of Pakistan, as it had joined the Superpower in the war, on the other hand, internal rifts started to foster which caused significant damage to Pakistan in the long term. The Counter Insurgency (In Aid of Civil Power) Regulation 2011 was promulgated especially to curb the menace of terrorist activities in problematic parts of federally administrated areas (FATA) and provincially administrated tribal areas (PATA). However, irrespective of all this legislation, due to its faulty court administration and low percentage of convictions along with terror financing allegations, Pakistan has been securing its position on the FATF grey list perpetually since 2018, which has become more challenging post-US withdrawal.

Nevertheless, the recent withdrawal of the US forces from Afghanistan after two decades has further complicated the security challenges for Pakistanas explained above. While it is too early to grasp the full implication of this evacuation of the US troops, one can say that the thing that remains steady is the precarious position of Pakistan on the regional and international stage. Pakistan is now at the edge of being caught between a bitter Washington and an encouraged and well-supported Taliban regime, along with her internal rifts. As explained, Pakistan has multiple religious factions divided on the political stance of the Pak-US-Afghan triumvirate. Though Pakistan seems to have a politically negotiated placement in the region with Afghanistan, internally, it requires a legally motivated robust counterterrorism regime with more strategic prudence.

\section{Road ahead and recommendations}

$\mathrm{P}$ akistan is undoubtedly in a perplexing situation for being an active ally in the war and now in the post US withdrawal phase. This phase has required Pakistan to take effective 
measures to strengthen its counterterrorism regime to deal with threats at international and national level. Though terrorism has declined significantly in Pakistan, the underlying roots are still spread out. Sectarian violence, porous borders, disturbances in Baluchistan, religious intolerance, animosity against the West, have all contributed towards and accelerated the threat of terrorism in Pakistan. According to the South Asian Terrorism Portal (SATP, 2021), Pakistan's security issue worsened in 2020 from 2019. According to the same assessment portal, Pakistan has taken significant measures to remove the harm done to its image being added to the FATF grey list. The highlights of the steps taken by the present government of Pakistan in Feb. 2021 were the arrest and conviction of Zaki-urRehman, leader of Lashkar-e-Toiba (LeT) and the arrest and conviction of the leaders of Jamat-ud-Dawafor financing terrorism. However, the most controversial arrest was of Hafiz Saeed, leader of LeT. Nevertheless, there has been speculation that Hafiz Saeed's arrest was a farce that made all the efforts of Pakistan look superficial (SATP, 2021). It is pertinent to mention that recently, a deadly bomb blast took place near his residence and an American citizen was arrested as a suspect (Aljazeera, 2021). All this somehow presents the picture that Pakistan has a long way to go regarding the religious factions present and working there to eliminate terrorism from its land. Also worthy of mention, the strong probability of an alliance between the proscribed organisations in Pakistan and the Taliban of Afghanistan.

Beginning in early July 2020, Tehreek-e-Taliban Pakistan (TTP) surprised observers by announcing a string of mergers with influential commanders and rival groups. According to the UN, the unification "took place in Afghanistan and was moderated by Al-Qaeda." (Economic Times, 2021) Events like the recent killing of four militants in Baluchistan allegedly belonging to the Baluch Liberation Army (BLA) by the counterterrorism department (Dawn, 2021), the claiming of a total of 13 attacks resulting in 77 casualties (killed and wounded) in 2020 by the Islamic State-Khorasan (ISIS-K), the TTP claiming 16 attacks that targeted civilians, with 14 deaths, and the terrorist attack in Quetta by TTP. On 21, April 2021 led the Security Council to issue a press statement declaring that any act of terrorism is criminal and unjustifiable (United Nations Security Council, 2021). Five soldiers from Frontier Corps, Baluchistan, were martyred after terrorists targeted a patrolling party in Sibi district on 25, June 2020 (Siddiqui, 2021). Terrorism attacks increased from 284 in 2019 to 319 in 2020 (SATP, 2021).

All these incidents lead us to the indication that there is extreme deterioration in the security situation of Pakistan. To date, Pakistan remains in the grey list of FATF and this causes concern for the international community and Pakistan (The Indian Express, 2021). The internal and external threats in Pakistan will get worse until the stable and politically powerful government in Afghanistan takes over. Pakistan needs to work on strategic deficiencies in its anti-terrorism legal regime to make the substantive legislation more dynamic with an explicit and transparent procedure.

\section{Recommendations}

$\mathrm{U}$ ndoubtedly, Pakistan suffers from structural problems, political manipulation, a lack of training and the lack of an effective responsive mechanism in law enforcement agencies and judiciary, which hinders the productivity and efficiency of existing counterterrorism strategies. Pakistan therefore needs to immediately introduce structural reforms in judiciary and law enforcement agencies.

From the above discussion, it is apparent that Pakistan needs to strengthen the management and coordination between the provincial and federal set up and that can be possible by strengthening the NACTA. Moreover, capacity building of the judiciary is needed urgently 
as due to the religious aspect of the terrorist activities in Pakistan, the judiciary has found itself in a fix while deciding on cases and, consequently, it is important to train the judges to deal with such sensitive cases. Additionally, it is important to provide the judiciary with explanatory notes and clear policy guidelines in order to avoid ambiguities attached with provisions of the Act. It is also paramount to keep a check and balance on the multiple or confusing interpretations by the judges. Moreover, to strengthen the criminal procedure a special cadre of investigators needs to be established: this will help to avoid any disparity and lacunas in the procedure of investigation. As always viewed as a safe haven for terrorists, Pakistan requires a comprehensive plan to counter the menace of terrorism. It is recommended that the policy should not only target terrorist activities but also should lay out a strategy to deal with the rising trend of radicalism, which is one of the basic root causes of terrorism.

Furthermore, Pakistan should draft counterterrorism policies while keeping in mind the size and scale of the acts, duration of conflicts, means and methods of uses, deployment of resources etc. to distinguish terrorist acts in peacetime than the anti-state terrorist acts. This distinction is necessary for effective procedural purposes and also to make the counterterrorism regime stronger and more effective. Additionally, it is recommended that Pakistan should consider the "Regulations of Investigatory Powers Act 2000 (RIPA) in the United Kingdom" (The Stationery Office Limited, UK, 2000a, 2000b) and "Foreign Surveillance Act of 1978 (FISA) in the United States of America” as model laws to draft its future policies. Through such legislation, Pakistan will be able to use modern techniques of interception of communication to deter terrorist acts. Furthermore, to make its criminal justice system more responsive towards the counterterrorism regime, Pakistan needs to make a shift from traditional testimony of witnesses and to incorporate other technological evidence which is already supported by the Qanoon-e-Shahadat Article 164 of Pakistan (QSA) (Law \& Justice Commission of Pakistan, 2021). Nevertheless, with the already mentioned recommendations, innovative prosecution techniques need to be encouraged and employed.

This research alludes that Pakistan's state policies direly need reform in the security sector due to changing conceptions of security over the past decade. Without a doubt, Pakistan and its people have suffered a lot during this War and Pakistan should introduce structural and institutional changes to create a people-focused conception of security. Nevertheless, it is true that Pakistan is a developing state and its actions based on resources cannot be compared with developed states. However, the responsibility is on the legislature to draft a comprehensive robust mechanism to counter the menace of terrorism. This paper concludes that Pakistan, to date, has been unable to implement effective counterterrorism strategies due to its poor regulatory system. Also, constitutionally, Pakistan needs to work on its federal and provincial administrative balance. The overlapping of legislation such as the ATA and POPA indicates that some hazy boundaries need to be looked at. Certainly, there are numerous shortcomings in the counterterrorism legislation of Pakistan, as discussed above, which is aggravated by security-related defects, constitutional and legislative framework failures and ineffectiveness of law enforcement agencies. Unquestionably, Pakistan has a strong commitment to eradicating terrorism from its land, although what it requires is a more focused, balanced and committed approach.

\section{Funding}

This research received no external funding.

Data availability statement

Not applicable.

The author has read and agreed to the published version of the manuscript.

Disclosure statement

No potential conflict of interest was reported by the author. 


\section{References}

Al Jazeera English (2021) Three killed in blast near LeT founder Hafiz Saeed's Lahore home. Available at: https:// www.aljazeera.com/news/2021/6/23/pakistan-blast-hafiz-saeed-lahore-residence (Accessed: 24 June 2021).

Bhatti, H. (2021) SC orders release of prime accused in Daniel Pearl murder. Available at: https://www.dawn.com/ news/1604095 (Accessed: 22 June 2021).

Dawn (2010) Marriott bombing accused acquitted. Available at: https://www.dawn.com/news/852088/marriott-bombing-accused-acquitted (Accessed: 24 June 2021).

Dawn (2021) Four "militants" killed in gunfight with CTD personnel. Available at: https://www.dawn.com/ news/1629946/four-militants-killed-in-gunfight-with-ctd-personnel (Accessed: 25 June 2021).

Economic Times (2021) Moderated by Al-Qaeda, TTP oversaw reunification of splinter groups in Afghanistan: UN. Available at: https://economictimes.indiatimes.com/news/defence/moderated-by-al-qaeda-ttp-oversawreunification-of-splinter-groups-in-afghanistan-un/articleshow/80721988.cms?from=mdr (Accessed: 25 June 2021).

Fair, C. Ch. (2012) 'Pakistan in 2011: Ten years of the "war on terror"', Asian Survey 52(1), pp. 100-113. doi: $\underline{10.1525 / \text { as.2012.52.1.100. }}$

Imran, M. and Qasim, R. (2020) 'Anti-terrorism legal framework in Pakistan and challenges before the criminal justice system', Pakistan Journal of International Affairs, 3(2), pp. 236-262. doi: 10.52337/pjia.v3i2.22.

Kennedy, Ch. H. (2004) 'The creation and development of Pakistan's anti-terrorism regime, 1997-2002', in Limaye S.P., Malik, M. and Wirsing, R.G. (eds.) Religious radicalism and security in South Asia. Honolulu, Hawaii: Asia Pacific Centre for Security Studies, pp. 387-411. Available at: https://apcss.org/wp-content/ uploads/2011/03/PagesfromReligiousRadicalismandSecurityinSouthAsiach16.pdf. (Accessed: 30 June 2021).

Law \& Justice Commission of Pakistan (2021) Law of Evidence. Available at: http://www.ljcp.gov.pk/Menu\%20 Items/Publications/Reports\%20of\%20the\%20LJCP/reports/report06.htm (Accessed: 26 June 2021).

Looney, R. (2004) 'Failed economic take-offs and terrorism in Pakistan: Conceptualizing a proper role for U.S. assistance', Asian Survey, 44(6), pp. 771-793. doi: 10.1525/as.2004.44.6.771

Malik, Z., He, Z. and Rafay, M. (2019) 'War on terrorism in Pakistan: Challenges and strategic steps', Vestnik RUDN. International Relations, 19(4), pp. 625-631. doi: 10.22363/2313-0660-2019-19-4-625-631.

Michael, S. (2007) 'Terrorism a socio-economic and political phenomenon with special reference to Pakistan', Journal of Management and Social Sciences, 3(1), pp. 35-46.

Nasr, V.R. (2000) 'International politics, domestic imperatives, and identity mobilization: Sectarianism in Pakistan, 1979-1998', Comparative Politics, 32(2), p. 171. doi: $10.2307 / 422396$

Pakistani.org. (2018) The Constitution of Pakistan. Available at: http://www.pakistani.org/pakistan/constitution/ (Accessed: 5 June 2021).

Public Law 95-511 95th Congress An Act [online]. Available at: https://www.govinfo.gov/link/statute/92/1783 (Accessed: 29 June 2021).

Public Procurement Regulatory Authority (Pakistan) (2001) Anti-terrorism (amendment) ordinance, 2001 (August 14, 2001), to the ATA, 1997. Islamabad, Pakistan: PPRA. 
Refugee Review Tribunal Australia (2008) Available at: http://www.refworld.org/pdfid/4b6fe2e30.pdf (Accessed: 15 June 2021).

Research Society of International Law (RSIL) (2013) The case for a change, a review of Pakistan's Anti-Terrorism Act of 1997. A report by the RSIL. Islamabad, Pakistan: RSIL.

Siddiqui, N. (2021) 5 FC men martyred in Sibi terrorist attack: ISPR. Available at: https://www.dawn.com/ news/1631390 (Accessed: 25 June 2021).

South Asia Terrorism Portal (SATP) (2021) Terrorism assessment, Pakistan. Available at: https://www.satp.org/ terrorism-assessment/pakistan (Accessed: 20 June 2021)

Supreme Court of Pakistan (1998) Mehram Ali versus Federation of Pakistan. PLD 1445. Islamabad, Pakistan: Supreme Court of Pakistan.

Supreme Court of Pakistan (1999) Sheikh Liaqat Hussain and others vs. Federation of Pakistan. PLD 504. Islamabad, Pakistan: Supreme Court of Pakistan.

The Indian Express (2021) Pakistan to remain on FATF grey list. Available at: https:// indianexpress.com/article/pakistan/fatf-pakistan-grey-list-terror-financing7375835/ (Accessed: 28 June 2021).

The Nation (2015) POPA and political victimisation. Available at: https://nation.com.pk/20-Oct-2015/ popa-and-political-victimisation (Accessed: 20 June 2021).

The Stationery Office Limited, UK (2000a) Regulation of Investigatory Powers Act 2000. Available at: https:// www.legislation.gov.uk/ukpga/2000/23/contents (Accessed: 29 June 2021).

The Stationery Office Limited, UK (2000b) Regulation of Investigatory Powers Act, 2000, 48 Eliz. 2. Available at https://www.legislation.gov.uk/ukpga/2000/23/pdfs/ukpga 20000023 en.pdf (Accessed 29 June 2021).

The Foreign Intelligence Surveillance Act of 1978 (FISA). Available at https://bja.ojp.gov/program/it/privacy-civil-liberties/authorities/statutes/1286 (Accessed: 20 June 2021).

United Nations (2019) Welcome to the United Nations. Available at: https://www.un.org (Accessed: 29 June 2021).

United Nations Security Council (2021) 'Security Council Press Statement on Terrorist Attack in Quetta, Pakistan’. Available at: https://www.un.org/press/en/2021/sc14504.doc.htm (Accessed: 30 December 2021).

United Nations Office on Drugs and Crime (UNODC) (2008) UNODC/TBP workshop on international cooperation in terrorist cases, Vienna 25-27 August 2008. Available at: http://www.sindhhighcourt.gov.pk/downloads/ source files/UNODC.pdf

US Congress (2006) Foreign Intelligence Surveillance Act of 1978, Pub. L. No. 95-511, 92 Stat. 1783 (codified as amended at 50 USC. \$\$1801-1811 [2006]).

US Department of State (2006) International terrorism resolutions. Available at: https://2001-2009.state.gov/s/ ct/intl/c4353.htm (Accessed: 30 June 2021). 